\title{
Readers Theater as a Tool to Understand Difficult Concept in Economics
}

\author{
Dwi Wulandari ${ }^{1} \&$ Bagus Shandy Narmaditya ${ }^{1}$ \\ ${ }^{1}$ Faculty of Economics, Universitas Negeri Malang, Indonesia \\ Correspondence: Dwi Wulandari, Faculty of Economics, Universitas Negeri Malang, Indonesia. E-mail: \\ dwi.wulandari.fe.um@ac.id
}

Received: November 21, 2016

Accepted: December 30, 2016 Online Published: April 29, 2017

doi:10.5539/ies.v10n5p144

URL: https://doi.org/10.5539/ies.v10n5p144

\begin{abstract}
Readers Theater is one of the innovative learning in an effort to increase the understanding and value students' learning processes that involve the activity of reading, writing, listening and speaking. In this type of learning, students read a manuscript of a certain literature and other students grasp the meaning of what was read and is shown by the reader. Readers Theaters are different from playing drama. In the drama needed costumes, setting room etc., but in this learning not required. Is the key to effective learning is clearly read the script readers, and listeners can clearly visualize from what is shown. This paper used readers theater to teach a topic of macroeconomics which is unemployment that often considered as a hard topic. We found that students are very happy with this method. Their reading, writing, listening and speaking activities are improving and the most important thing is their understanding of unemployment topic is so much better compared to teaching them with the only direct instruction method. One of the parts that should not be forgotten by teachers is debriefing to check the understanding of the students and many students want this method to be continued especially for another difficult topic so it will be easy to understand.
\end{abstract}

Keywords: readers theater, teaching method, macroeconomics, unemployment

\section{Introduction}

Economics sometimes assumed as a difficult subject. Some topics are assumed very hard to understand and sometimes for students, especially in Senior High School it can only be memorized when they have tests and suddenly forget everything whenever the test is over. As a life skill, economics should not only be memorized and forgotten but also be understood so it can be applicable in daily lives.

Macroeconomics is a branch of economics dealing with the performance, structure, behavior, and decision-making of an economy as a whole market rather than individual markets. This includes national, regional, and global economies (Blaug, 1985). Macroeconomists study aggregated indicators such as Gross Domestic Product (GDP), unemployment rates, national income, price indices, and the interrelations among the different sectors of the economy to better understand how the whole economy functions. Macroeconomists develop models that explain the relationship between such factors as national income, output, consumption, unemployment, inflation, savings, investment, international trade and international finance. While macroeconomics is a broad field of study, there are two areas of research that are emblematic of the discipline: the attempt to understand the causes and consequences of short-run fluctuations in national income (business cycle), and the attempt to understand the determinants of long-run economic growth (increases in national income). Macroeconomic models and their forecasts are used by governments to assist in the development and evaluation of economic policy.

When talking about topics in macroeconomics, students have the tendency to think that the topics are not related to their real life. They think that this is a state problem that will not influence their lives. Some students find these topics hard to understand and they think it's not their level to understand these topics. They have the tendency to memorize these topics for test and forget them as soon as they finish the test.

This is not entirely true. Some topics in macroeconomics are really related to our daily lives for example inflation. Even though inflation data are conducted by Central Bank and published monthly, many students do not really understand or care about this phenomenon because they think it does not relate to their daily lives. But 
the truth is, every time they used their stipend to buy something and suddenly the prices were increasing, they find it is not comforting because they will have fewer goods. They need to understand that what happened here is the phenomenon of inflation. When high inflation occurs, it affects students' daily lives. That is why they need to really understand this topic.

Another example is unemployment. Why should students be aware of definition, causes, types and solution for unemployment? At first they will not care about this and will only memorize these things for test but after they know that types of unemployment will affect their lives and if they know this phenomenon, they will be able to prepare themselves and their ability to face the job seeking competition, they begin to understand that understanding this topic is extremely important.

When we surveyed the students, from basic macroeconomics concepts such as output and income, unemployment, inflation and deflation, students find that unemployment is the hardest topic. Unemployment is a complex issue and an issue experienced by each State. We recognize the existence of natural unemployment, frictional unemployment, and structural unemployment. When calculating the unemployment we can divide the number of unemployed to the total labor force multiplied serratus percent. Unemployment occurs due to several things and is a complex thing. The unemployment caused by the time it takes workers to find a job is called frictional unemployment. Economists call a change in the composition of demand among industries or regions a sectoral shift. Because sectoral shifts are always occurring, and because it takes time for workers to change jobs, there is always frictional unemployment (Mankiw, 2008).

While some types of unemployment may occur regardless of the condition of the economy, cyclical unemployment occurs when growth stagnates. Okun's law represents the empirical relationship between unemployment and economic growth (Dwivedi, 2001). The original version of Okun's law states that a 3\% increase in output would lead to a $1 \%$ decrease in unemployment (Neely, 2010).

Related issues that are difficult to understand the problems of the economy, the use of game-based learning methods and simulation is suitable to specify in the learning economy. With the development in the context of the situation and the situation of students role playing and simulations be appropriate to increase understanding. Wulandari and Narmaditya (2016) explain that the use of simulation learning method can improve the understanding of the learning activity and capital market-related economy. Scutliffe (2002) explains that Role playing as a learning approach that is often used is often equated with the context of gaming and simulation. Learning to use can increase the attention of students. In that article also explained that simulations become role-plays when the student is expected to act as they imagine appropriate to a given role. For Example, the may be asked to act as a stockbroker in a share-dealing simulation or as the Chancellor of the Exchequer in managing the economy. The opportunity for the student to act out the role is bounded by the rules of the simulation and the degree to which the simulation is constructed as a game. As games usually require tight rules, role-plays are likely to give more scope for the student to exercise their own interpretation of the role when the simulation is not constructed as a game (Scutliffe, 2002).

The use of role playing is often said can improve the students to reflect on their knowledge and draw together the various dimension of their course of study. The teacher can also control over the process and outcomes of learning. Role playing is also excellent approach by which to develop in students a greater appreciation of role and responsibility. Students achieved a deeper understanding of their own views and those of others. Role playing, especially when a group based, have contributed to a positive change in classroom dynamics. They help break down barriers and stimulate a greater level of long-term interactivity between students. Theoretical concepts can be given life by placing them in a situation with which student are familiar (Sutcliffe, 2002).

Another Studied by Neral and Ray (1995) in discussing the merits of teaching costs and production via a game, remark that 'many of the students in our introductory courses have difficulty in dealing with the high level of abstraction that permeates economic theory, and it can be extremely helpful to provide these students with concrete examples of the phenomena that the theories attempt to describe. Francis and Byrne (1999) found that one of the greatest benefits from conducting a role-play exercise amongst undergraduate astronomy and physics students was that it changed classroom dynamics into a noticeably more interactive and friendly environment. They felt that the role-play they used broke down the barrier.

Allan (2015) explains that the ultimate goal of most role playing not only to see the winning and losing but also more pressing teamwork. In the role playing is highly dependent on the action of the perpetrators, as in if there is a mistake in the team will make the game did not go well and fun. Role-playing adds to already effective learning tools within supply chain management such as simulation and gaming. Role-playing games are designed from the ground up to be cooperative and it can be a lot of fun to play a game where there are no winners and losers. A lot of 
games strive to be competitive, but life can be competitive enough, and role-playing games provide a refreshing change of pace. Additionally, learning to be a team player is highly important in the professional world. You take on a role at work and do the things that you've trained to do, and it works the same way in a role playing game. Your character normally has a particular skillset, and that fills a role on a diverse team. Just like at work, if you don't do your job, the whole team can suffer for it (Allan, 2015).

Readers Theatre is another useful teaching strategy where the students orally participate in reading poetry. Gestures and actions may be applied to enhance understanding and learning. Groups of students may share their creative interpretations or role plays related to Readers' Theatre. There are a number of websites for Readers Theatre or teachers can create their own texts for active, kinesthetic readings. These activities encourage active listening, speaking and action performance in response to the words of the poetry. Multiple perspectives and interpretations may be presented by different student groups, which encourage a variety of possible readings (Ashton-Hay, 2005).

One of the methods of role playing is Readers Theatre. Readers Theater is a minimal theater in support of literature and reading (Sherpard, 2004). Readers Theater does not require costumes, sets, props, memorized lines, lighting, sound, or any other devices normally associated with technically oriented theatrical performances (Cornwell, 2012; Grafton \& Cross, 2008). If used at all, costumes are partial and suggestive, or neutral and uniform, no full memorization. Scripts are used openly in performance. Reader theater is one effort that is effective, efficient and enjoyable learning to present problems or material in the form of dramatic. Usually in Readers theater adopting from various sources or literacy and adopt it. Readers theater is developed in the university and is currently also developing a low level of education where this is the creative effort to increase the desire and the skill of reading. The explanation of this model is suitable for use in all types of education. Not only was another interesting thing is the cooperation between groups that support the reader theater going well and achieve objectives. Moreover, Shepard (2004) explains that readers theater is a relatively simple activity for the teacher, with no required setup other than making copies of scripts (Shepard, 2004).

Readers theater has been found effective not only for language arts but for social studies as well (Shepard, 2004). Performing stories based on another culture is one of the best ways for students to become interested in and familiar with that culture. Readers theater is incomplete without an audience. Readers Theater (RT) is a dramatic reading strategy in which a play, narrative poem, speech, or a dramatic piece of writing is formatted into a script and read aloud to a live audience (Willcutt, 2007). The players speak to be heard, and audience members listen to respond. Sloyer (2003) explain the benefits that accrue from incorporating readers theater into the classroom are many. Engaging students in the art form of dramatizing literature motivates them to read willingly, think critically, write creatively, speak correctly, listen intently, and work together productively. It will improve the students to share knowledge and literature, reading aloud to write scripts, perform with the objectives and work collaboratively.

When effectively implemented, it immerses students in reading aloud, sharing literature, writing scripts, working collaboratively and performing with a purpose (Cornwell, 2012). Readers Theater is readers reading a script adapted from literature, and the audience picturing the action from hearing the script being read aloud. It requires no sets, costumes, props, or memorized lines. Instead of acting out literature as in a play, the performer's goal is to read a script aloud effectively, enabling the audience to visualize the action. Performers bring the text alive by using voice, facial expressions, and some gestures (Cornwell, 2012).

According to Mace (2015), while social studies teachers may struggle to find the time or resources to put on a full-scale theatrical production, the readers theater is a style of drama that most teachers can easily use in the classroom. Research has shown that readers theater, or RT, not only enhances students' speaking and listening skills but also boosts their vocabulary and reading fluency as they practice and reread texts. These are valuable results, especially when we consider that literacy skills are now emphasized and integrated into standards across all curriculums and subject areas. Additional benefits of the reader's theater are its encouragement of peer interaction and cooperation and its ability to generate enthusiasm for reading tasks. Unlike traditional theater production, RT does not require costumes, sets, or memorization; all that is needed is imagination. Once they are well-versed in the techniques of RT, students can create their own scripts. Younger students can adapt picture books and early readers, and older students can write original plays or adapt news stories, speeches, or works of literature. The Federal Reserve has created a number of readers theater scripts that teachers can use to teach economics and personal finance. Following is a guide to these scripts and to the concepts they teach, sorted by grade level. Also listed is a lesson from the New Deal Networks Great Depression and the Arts curriculum, which uses numerous primary sources and actual scripts from the New Deal's Federal Theater Project to teach about the social, economic, and political issues of the Great Depression. 
Regarding the cultural background of students in Indonesia, they are still lack of inability to express their ideas in front of the public. Many of them are passive students and have the tendency to only listen to teacher's explanation in class. By applying Readers Theatre, students can improve their ability to speak in front of the public and express their ideas. The democratic climate in class will increase and students can be more creative.

We can assume that Readers Theatre is a strategy to improve students' reading fluency, interest, and understanding of the content material. Starting a new style to present the drama in the 1950s. Switching to drama education, reading, and language education, but are now used in a variety of subjects and at all grade levels. Points of key to Teaching are the stage and equipment were minimal, no need to memorize-actor reading from a script, narrator (usually a teacher) to prepare, use classrooms to emphasize the expressive readings and frequent audience participation, it may take the example of the teacher and/or a quick exercise by students, scripts can be developed from/by novels, stories, poetry, biography, or other historic documents, teachers, students.

\section{Methods}

We tried this role playing method (Readers Theater) in eleventh-grade students of Senior High School on the topic of Unemployment. Unemployment may be the result of declining output and rising employment in the number of workers needed. This is the main focus of macroeconomic since these represent unused resources that can be used to produce additional goods and services. The students take part in the play to learn about the problem of unemployment. They then participate in activities that help them to be skilled to operate effectively with special content related to the topic of unemployment. The goals of this role playing method is to explain how unemployment is measured and describe the four types of unemployment. It will take one school hour. The students read the script out loud and do not need to memorize this script. The script are adopted from Council For Economic Education (2009). The procedure is as follows:

1. Introduce the study of unemployment by telling students that it is the other important variables, apart from GDP and inflation, in the study of macroeconomics. Explain that economists focused their attention directly on unemployment and only indirectly on the use of labor (employment) for unemployment represent unused resources.

2. Explain that the participants will take part in a play that depicts the debate between the two candidates on television. Topics of the debate are unemployment. Explain that the play is a script that is read (reader's theater) and that each participant has a role.

3. Meet the main character and explain that they do not have the role of the individual and they become the community. Set the stage as necessary and provide available equipment.

4. Share a copy of activities to those which are part of the community.

5. Allow time for the theatrical presentation. When the play has finished, debrief using the following procedure:

a. Ask "Who is unemployed?" (People aged 16 years and over and are actively looking for work).

b. Ask, "Why unemployment is a problem?" (Because it raises an important negative effect on society. It is wasting resources, lowering living standards, involving the economic and social costs).

6. Discuss the implications of unemployment, use the production possibilities frontier (PPF). Stress that: Resources that are unemployed is illustrated by the points under the PPF, Goods that are produced decreases when resources are not fully used.

a. Ask "What is the status of the characters in the play: whether they are employed or unemployed?" (Everything worked, except members of the Jobson family).

b. Ask, "Why is the youngest member of the Jobson family considered unemployed?" (Because he is over 16 years old, able to work and actively looking for work).

c. Ask "What is the main impact of unemployment on individuals?" (People who are unemployed usually lack the income to purchase goods and services compared with those who have jobs).

d. Ask "Are some people may be unemployed because they face discrimination?" (Yes). Explain that the unemployment rate for people of different ages, races, and sexes are different. This reflects differences in work experience, education, training and skills, as well as discrimination.

Discuss the concept of employment and unemployment. Remember that these terms may be defined in different ways in different countries. In the United States, the unemployment rate is taken from a national survey of about 60,000 households conducted every month, asking the status of their work aged 16 years and over. A number of people who are working or looking for work can be estimated very accurately from the survey data. The 
percentage of workers who do not work computed by dividing the number of people looking for work (unemployed) with actual labor and multiplying the result by 100. In Indonesia according to Sakernas (State of National Labour Force Survey), unemployment is defined as follows those who are looking for work and when it does not work, they are preparing for a business that is an activity undertaken by a person in order to prepare a business or a new job, those who do not seek work, because they feel it is impossible to get a job, this is called a desperate unemployed, those who already have a job, but have not yet started work.

7. Show that many countries measure labor data regardless of the military. This is known as the civilian labor data. Show why this data is more useful to government policy decisions.

8. Back to the discussion about the play and ask "How President calculate the unemployment rate?" (He calculated the unemployment rate as a percentage of the workforce who are considered unemployed). Ask, "Why do the candidates question the accuracy of the unemployment rate?" (The standard measure of unemployment is not perfect).

9. Discuss the following things: the unemployment rate is an imperfect measure of unemployment because it does not include workers that their job prospects are so low that they have lost the spirit to find a job and because it does not reflect part-time workers seeking full-time employment.

a. Ask "What is meant by the President with the use of full employment?" (At this point the level of full employment is considered as approximately $93-97 \%$ of the workforce, allow frictional unemployment is around $5-7 \%$ ). What the reason that the President said that the natural rate of unemployment is $5-7 \%$ ? (The lower unemployment rate is expected to lead to inflation).

10. Note that unemployment may arise from changing jobs, seasonal fluctuations in demand, changes in the skills required by employers or cyclical fluctuations in the level of national spending. Discuss the three main types of unemployment. Show that some economists distinguish between frictional unemployment and seasonal, while others incorporate seasonal in frictional. Ask the participants if the three types of unemployment were alluded to in the play? (Yes).

11. Remind participants that frictional unemployment is short term unemployment associated with the transition into the labor market, such as people change jobs, or into the workforce for the first time. Ask participants to give examples of frictional unemployment in the play (Mrs. Jobson and Bill Jobson).

12. Structural unemployment is the kind of unemployment caused by changes in the economy, which resulted in a mismatch between the skills and location of those seeking employment with the requirements and the location where the availability of the job. Ask participants to give examples of structural unemployment in the play. (Mr. Jobson)

13. Cyclical unemployment is the kind of unemployment caused by fluctuations in the level of overall economic activity,

a. Ask participants to give examples of cyclical unemployment in the play (Jill Jobson).

b. What the President expressed as appropriate policies to address structural unemployment? These policies include educational programs and training. A decrease in the minimum wage and the level of discrimination can also help.

c. How Mr. Dolittle plan to address cyclical unemployment if elected? (Cyclical unemployment can be reduced through policies that stimulate demand: e.g. tax cuts, government spending on public works programs)

14. Introduce the concept of potential labor and the labor participation rate. In some countries, the potential labor force is called "population who meet the age requirements" and is usually measured by the whole population is reduced by (1) people youth under 15 or 16 years, and (2) those who are in institutions (inmates in prisons or mental hospitals, sanitariums, elderly homes, hospitals or displaced people).

15. Tell participants that the new teaching strategies used so-called "Readers Theatre" (manuscript reads) or RT. Ask what are the main features of that strategy (The answer may vary, but can include students play a particular role, little equipment or altogether, audience participation).

16. Ask such strategies can be designed to achieve what? (Answers will vary, but may include increasing students' reading fluency, interest, and understanding of the content of the material).

17. Read the definition of Readers Theatre: "A strategy to improve students' reading fluency, interest, and understanding of the content material". Briefly tell the history of RT. Talk Points of Primary Teaching of RT 
and compare it with the list made by the class. Note that almost all the texts can be used as a source of RT and the actual script can be prepared by teachers and students themselves.

\section{Result and Discussion}

We give this script to the students and choose them to play the characters in this script. The rest of the students became the audience (community) who were cheering and clapping their hands at the moment we decided. This is to make every student felt involved in the role play and pay attention to the concept. Here is the script (CEE, 2009):

A voice from above: Helloooo! Welcome to meet again in the event the most watched TV today: "I Want To Be President".

Moderator: Good evening everyone, I'm Mike Screeny, and I am pleased to welcome you back on the television show "I Want To Be President!" (Applause and cheering). As in previous episodes, the special guests we are both candidates in the presidential elections to come (refer to the two candidates in turns). Head of governance today, supported by the Prosperity Party, Mr. Bob Dolittle!

Attendance: Woohoo!!!! (Clapping and waving).

Moderator: And the challenger, supported by the Welfare Party, Mr. Jim bigdeal!

Attendance: Woohoo!!!! (Clapping and waving).

Moderator: The topic tonight timely and important: Unemployment

Attendance: uuuuuuu!

Moderator: Yes! You are of course very excited about this topic. Not many things can be frightening and harmful to people like unemployment. Unemployment means (counting fingers): wasted labor, lower the standard of living, additional costs to society of having to support people who do not work. Do we want unemployment?

Attendance: (excited): Noooo! We want the occupation! We want to work!

Moderator: (satisfied): Oookee... hey... I hear you. Now let's see how our guests are planning to face the problem of unemployment. They should explain their ideas to you, the audience, and to the Jobson family. This family represents those who are unemployed.

Jobson Family: Stand up and salute the audience.

Attendance: Woohoo!!!

Moderator: Their situation is very severe and unusual. Everyone in the family is unemployed.

Attendance: Ooooooh!

Moderator: Yes, they are unemployed.

Mr. Bigdeal: Being nervous and started flipping through the paper.

Moderator: You will hear the story of the Jobson family later. Now we will hear from the candidates.

Mr. Bigdeal: Looks more nervous and want to talk.

Moderator: Yes, Mr Bigdeal, if you want to say something? Please.

Mr. Bigdeal: I am sad to hear the tragic situation of the Jobson family. But I am not at all surprised, and I'll bet this is not the only case. I bet this happens often. Allow me to share some information that can help everyone to understand what is happening in this country. There are 20 million people living in this country, but only 8 million are working and earning.

President Dolittle: Mr Bigdeal, allow me to give you a little information. In addition to the 8 million workers, you should add 1.2 million more to run their own business and self-employment. So people who work in our country is almost...

Attendance: Half!

President Dolittle: 8 plus 1.2 is 9.2 million. Not until, but almost half of the total working population. Do you mind if we say half? (To the audience) Thank you.

Mr. Bigdeal: Less than half? And it sounds good?! What about the other half?

President Dolittle: They may be too young, or pensions, or in institutions, or they choose not to work. Nobody 
counts them as part of the workforce. The labor force is people aged 16 and over who are working or actively looking for work. So our labor situation is not as bad as you try to draw.

\section{Attendance: Clapping}

Moderator: But Mr. Dolittle, maybe not all people who become part of the workforce is working. Because if so, we will not hear about unemployment.

Jobson Family: Yes, that's right, that's right.

Mr. Bigdeal: There were 400,000 people unemployed four years ago, today there are 800,000 . I do not know how true these numbers; for me it still seems poor. But I agree to use it as the basis for our discussion.

Attendance: Clap hands.

Mr. Bigdeal: So Mr President, what people have to understand when unemployment is doubled?

President Dolittle: I think we need to talk more about unemployment so that people can understand. With those numbers and even then, we do not have what you need to make a comparison. So, first of all we need to calculate the unemployment rate. What if we do it together, Mr Bigdeal?

Mr. Bigdeal: (ironically) Of course, why not, Mr. President.

President Dolittle: (to the audience) It is a matter of simple arithmetic. First of all we must calculate the size of the workforce. The labor force is the number of people working plus the number of people who are unemployed. So it was 9.2 million plus 800,000 so it is., (Looking to Mr. Bigdeal)... it is (look again)... it is...

Attendance: 10 million.

President Dolittle: (to the audience) Yes. Thanks. Well, the unemployment rate is the percentage of the workforce who are considered unemployed. If the number of unemployed persons was 800,000 , and the workforce is 10 million, the unemployment rate is. (turned suddenly to Mr. Bigdeal) Mr. Bigdeal?

Mr. Bigdeal: Of the 10 million, 1 percent was 100 thousand. And 800 thousand means... (Glancing Moderator, seek help) Pak Mr. Screeny?

Moderator: moderator turned to the audience, asking for help.

Attendance: 8 percent.

President Dolittle: (to the audience) Yes. thanks.

Mr. Bigdeal: Good, 8 percent. That means the unemployment rate rose from $4 \%$ to $8 \%$ in the last four years. Is it not a big problem for the Government Dolittle?

Moderator: Is not that a sign of a deep recession?

Attendance: Recession? Deterioration ?! Uuuuuuhh!

Mrs. Jobson (to Mr. Jobson): How they can count on so quickly?

President Dolittle: I'm not proud and not happy with the fact that the unemployment rate rose to $8 \%$, but the situation is not so bad...

Jobson Family (astonished): Not so badly? It's easy if you say.

President Dolittle: Of course not. First of all, when the level is 4\%, we experienced a little over employment.

Jobson Family: (exasperated) Overemployment! What are you talking about?

Mr. Bigdeal: Sir, I do not know what you mean by over employment. But I think it should not be this hard to help people find and keep their jobs. What I'm interested in just an economic use of full labor, and I think I know how to achieve it!

Attendance: Clap hands.

Jobson Family: Jobson family clapped and cheered.

President Dolittle: The full employment, hmmph! No one is able to employ the entire workforce, all the time. People move from one place to another, they are looking for a job that gives a higher income, many of them work on a seasonal basis, for example in the field of construction. They may first seek work or perhaps while looking for a new job. This kind of frictional unemployment is unavoidable. And there is also a plus.

Mr. Bigdeal (refers to the Jobson family): But these people do not seek higher-paying jobs - they just want to find a job, period. 
President Dolittle: Let's think of other things happening. Economics itself changed, so did the market. Needs and preferences of consumers may be changed, improved technology, new products appear on the market and long products removed from the market. Profession tides, the employee gets a job and dismissed. I cannot control it, you cannot, and no one can. This so-called structural unemployment is at a certain level is also inevitable.

Mr. Bigdeal: Unavoidable? Again!

President Dolittle: Yes. And also because there are frictional and structural unemployment that we cannot avoid, the level of full employment is reached when approximately $93-95 \%$ of the workforce works. That means the natural rate of unemployment is $5-7 \%$. The natural rate can be tolerated and is not inevitable and to some degree even desirable.

All, except the President Dolittle and Moderator: Natural? (Ascending) can be tolerated? (Audience stands) Desirable? (They speak louder and louder, constantly repeating the three words).

President Dolittle (standing, raised both hands in the air and almost shouting): Yes, natural unemployment is desirable.

Moderator: Ladies and gentlemen, please

Spectators: Spectators still ranting while one by one began to sit up.

Moderator: Let's go back to our presidential candidates. Mr. Bigdeal, do you want to propose a solution?

Mr. Bigdeal: Yes, that's what I want to do. I want to create jobs. If I am elected, I will make the money work for people. (To the Jobson family) My job is your job (Jobson family are cheering excitedly) Thanks, many thanks. (To Mr. Jobson) Mr. Jobson, I hope you send your resume to me as soon as possible. I will try to do something for you.

Moderator: How about if we listen to their stories right now? Mr. Jobson?

Mr. Jobson: I worked at the old glass factory. We produce bottles and stuff like that. But the factory closed last year. People no longer need the bottle, everything now is using plastic containers.

Moderator: Unfortunately. Mrs. Jobson's?

Mrs. Jobson: For 23 years I was a housewife. Now my children are already big, but still in school. My husband has not worked since last year. So I decided it was time for me to work. But until now I have not been able to get a job.

Moderator: I'm afraid it will be difficult to get a job. Ms. Jobson?

Jill Jobson: Even though I was a college student, and I got a scholarship from the beginning, I still need to work to support myself, especially because my father lost a job. Until a few months ago I worked as a sales agent for the wholesaler that distributes household appliances. But the economy slowed and the business is not as much as before, then they began to lay off employees. The first dismissed employees are young part-timer.

Moderator: Do not despair. And finally, Bill junior.

Bill Jobson: I was 17. I was a high school student and I'm trying to find part time job to help my family. But I was not lucky.

Mr. Bigdeal: Mr President, what happened? We better get rid of poverty, unhappy, despair, discrimination, and various kinds of unemployment that can be imagined. But I think you also have an explanation for it.

President Dolittle: I think a bit of additional information can help. I became even more sorry for the Jobson family after hearing their story, but we should try to understand what happened. Junior and Mrs. Jobson is an example of frictional unemployment. They will be people who are new to the workforce. Yet they are also vulnerable to unemployment because their skills are limited. Mr Jobson was the victim of structural unemployment. His expertise is no longer fit the needs of the economy, and he must try to prepare himself for a new profession.

Moderator: What about discrimination, Mr. President?

President Dolittle: I'm not sure we can talk about discrimination in this case. Maybe there is a difference between the people and those with lower qualifications, which have more or less experience, more or less suited to the new technology and are not able to respond to changes in market demand has always been the first to suffer. So the core of my policies regarding unemployment is directed at these people. Education and training is the key. 
Moderator: Well, let's go to the end of our show.

Spectator (now really cheering): Lucky... One more week we would not care about the election...

Moderator: OK. OK. I see. Let's hear what both candidates would say.

Mr. Bigdeal: I want to go back to the case of Ms. Jobson. He clearly expressed that he lost his job because of reduced demand for consumer goods. This is not frictional unemployment, seasonal or structural. Is this not a clear sign that we are in a recession, Mr. President?

President Dolittle: I cannot deny that the economy experienced a slight decrease, and Ms. Jobson may be a victim of cyclical unemployment. But once again it is difficult to avoid, wherever the economy will slow down now or later, and then moved again to a new peak. Facing a cyclical movement even more difficult than controlling structural unemployment. Therefore I have decided to focus on structural changes to train and educate people for new professions and new technologies.

Mr. Bigdeal: With all due respect Mr. President, I do not believe it. The government should not ignore the recession. Believe me sir, I know. I was a successful businessman. Recipe for success is to maintain the demand remains high and low taxes to encourage spending and investment.

President Dolittle: Sure, but there are limits to what we can do. We cannot abolish the business cycle or the natural rate of unemployment.

Mr. Bigdeal (standing): Help me, please do not tell me again that 5-7\% of the workforce should not work. I do not agree with it and I do not believe these statistics. What about the people who have stopped looking for work or part-time workers are counted as full-time, there is a lot of miss-information. Actually, if we take into account all of this, the current unemployment rate should exceed $8 \%$ were reported. And I kept saying, no one is willing to work that does not get the job.

President Dolittle (also standing): And you think there is a way to make all of these people work and no more economic damage.

Mr. Bigdeal: Hear about the recent recession....

President Dolittle and Mr. Bigdeal: Both started talking very fast and at the same time to walk off the stage.

Moderator: Walking off the stage with the two candidates.

Audience: Start cheering, but stopped when the Jobson family stepped to the front desk.

Mr. Jobson: (to Mrs. Jobson) You know, Lizzy, I think when they asked us to come here, they are not willing to find a job for us.

Jobson Family: Jobson family waved to the crowd and walked off stage.

After performing Readers Theatre, we asked several questions to the students and compare the answers to the key answer (See methodology).

\begin{tabular}{|l|c|c|}
\hline \multicolumn{1}{|c|}{ Question } & Correct & Incorrect \\
\hline What is unemployment & $90 \%$ & $10 \%$ \\
\hline Why unemployment is a problem? & $70 \%$ & $30 \%$ \\
\hline What is the status of the characters in the play: whether they are employed or unemployed? & $100 \%$ & $0 \%$ \\
\hline Why is the youngest member of the Jobson family considered unemployed? & $50 \%$ & $50 \%$ \\
\hline What is the main impact of unemployment on individuals? & $80 \%$ & $20 \%$ \\
\hline Are some people may be unemployed because they face discrimination? & $50 \%$ & $50 \%$ \\
\hline How President calculate the unemployment rate? & $80 \%$ & $20 \%$ \\
\hline Why do the candidates question the accuracy of the unemployment rate? & $90 \%$ & $10 \%$ \\
\hline What is meant by the President with the use of full employment? & $90 \%$ & $10 \%$ \\
\hline The participants if the three types of unemployment was alluded to in the play? & $100 \%$ & - \\
\hline What the President expressed as appropriate policies to address structural unemployment? & $10 \%$ & $90 \%$ \\
\hline How Mr. Dolittle plan to address cyclical unemployment if elected? & $5 \%$ & $95 \%$ \\
\hline
\end{tabular}

For the first questions, what is unemployment, ninety percent of the students answer these questions correctly. The other ten percent said they forgot and concentrating more on the performance because they say it was really funny. This is a good result comparing to when we used conventional method in answering question, not many students can answer it correctly. The second question is why unemployment is a problem? The answers were 
varied especially most answer are unemployment leads to poverty and poverty leads to crime. We tried to emphasize that unemployment raises an important negative effect on society. It is wasting resources, lowering living standards, involving the economic and social costs. But students are having more creative answers compared to explaining this method in direct instruction. We discuss the implications of unemployment, use the production possibilities frontier and we stressed that resources that are unemployed is illustrated by the points under the PPF and goods that are produced decreases when resources are not fully used. The next question is what the status of the characters in the play is: whether they are employed or unemployed? All of the students agreed that everybody worked, except members of the Jobson family. We can see that all of the students at the classroom are paying attention to the play. When we asked why is the youngest member of the Jobson family considered unemployed? Fifty percent of the students are confused and thinking because Billy Junior is still in school. We tried to explain that Billy is above sixteen years old, able to work and actively looking for a job. When we asked what is the main impact of unemployment on individuals? The answers are varied but most of them relate this to poverty. Students think that if a person is unemployed, they will not have money to buy goods and services and it will lead them to poverty. When we asked is some people may be unemployed because they face discrimination? fifty percent of the students do not understand about discrimination so we need to explain it better to the students. We explain that the unemployment rate for people of different ages, races and sexes are different. This reflects differences in work experience, education, training and skills, as well as discrimination.

We discuss the concept of employment and unemployment. Remember that these terms may be defined in different ways in different countries. In the United States, the unemployment rate is taken from a national survey of about 60,000 households conducted every month, asking the status of their work aged 16 years and over. Number of people who are working or looking for work can be estimated very accurately from the survey data. The percentage of workers who do not work computed by dividing the number of people looking for work (unemployed) with actual labor and multiplying the result by 100. In Indonesia according to Sakernas (State of National Labour Force Survey), unemployment is defined as those who are looking for work and when it does not work, they are preparing for a business that is an activity undertaken by a person in order to prepare a business or a new job, those who do not seek work, because they feel it is impossible to get a job, this is called a desperate unemployed, those who already have a job, but have not yet started work.

We ask how President calculates the unemployment rate. Eighty percent of the students have the correct answer that the president calculated the unemployment rate as a percentage of the workforce who are considered unemployed. The other said that they are still confused about the measurement. When we ask why do the candidates question the accuracy of the unemployment rate? There is some variation of the answer from the students but mostly answer because it is not convincing and the standard measure of unemployment is not perfect. We explain that the unemployment rate is an imperfect measure of unemployment because it does not include workers that their job prospects are so low that they have lost the spirit to find a job and because it does not reflect part-time workers seeking full-time employment.

When we ask what is meant by the President with the use of full employment? Ninety percent of these students are confused because they have never hears about this before. We try to explain that at this point the level of full employment is considered as approximately $93-97 \%$ of the workforce, allow frictional unemployment is around $5-7 \%$. The reason that the President said that the natural rate of unemployment is $5-7 \%$ is that he lower unemployment rate is expected to lead to inflation. We add this explanation by describing Phillips curve. The Phillips curve is a single equation empirical model, named after A. W. Phillips, describing a historical inverse relationship between rates of unemployment and corresponding rates of inflation that result within an economy. Stated simply, decreased unemployment in an economy will correlate with higher rates of inflation. William Phillips, a New Zealand born economist, wrote a paper in 1958 titled The Relation between Unemployment and the Rate of Change of Money Wage Rates in the United Kingdom, 1861-1957, which was published in the quarterly journal Economica. In the paper Phillips describes how he observed an inverse relationship between money wage changes and unemployment in the British economy over the period examined. Similar patterns were found in other countries and in 1960 Paul Samuelson and Robert Solow took Phillips' work and made explicit the link between inflation and unemployment: when inflation was high, unemployment was low, and vice versa (Samuelson et al., 1960).

We explain that unemployment may arise from changing jobs, seasonal fluctuations in demand, changes in the skills required by employers or cyclical fluctuations in the level of national spending. Discuss the three main types of unemployment. Show that some economists distinguish between frictional unemployment and seasonal, while others incorporate seasonal in frictional. When we ask the participants if the three types of unemployment was alluded to in the play? All of the students stated yes. We remind participants that frictional unemployment is 
short term unemployment associated with the transition into the labor market, such as people change jobs, or into the workforce for the first time. Ask participants to give examples of frictional unemployment in the play. Eighty percent of the students answered correctly which are Mrs. Jobson and Bill Jobson. The other twenty percent needs more explanation since they seemed a bit confused with the play. Structural unemployment is the kind of unemployment caused by changes in the economy, which resulted in a mismatch between the skills and location of those seeking employment with the requirements and the location where the availability of the job. We ask participants to give examples of structural unemployment in the play. All of the students answered correctly which is Mr. Jobson. Cyclical unemployment is the kind of unemployment caused by fluctuations in the level of overall economic activity, we ask participants to give examples of cyclical unemployment in the play. Everybody answered Jill Jobson. We see that it is easier for the students to differentiate types of unemployment. When we ask what the President expressed as appropriate policies to address structural unemployment? Only ten percent of the students answered correctly so we explain to them that these policies include educational programs and training. A decrease in the minimum wage and the level of discrimination can also help. When we asked how Mr. Dolittle plan to address cyclical unemployment if elected? Policy seemed to be hard topics to understand, only five percent of the students answered correctly so we explain that cyclical unemployment can be reduced through policies that stimulate demand: e.g. tax cuts, government spending on public works programs.

We tell participants that the new teaching strategies used in this topic is Readers Theatre (manuscript reads) or RT. The main features of that strategy are students play a particular role, little equipment or altogether, audience participation. When we asked what they think about the method, ninety percent of the students felt that this method makes the topic more interesting and they are attracted more to this macroeconomics topics and they would like to have this kind of session again for another difficult topic. And since they do not need to memorize the dialogue and only read it, they think it is easy and can improve their reading fluency. The concept is easier to understand.

According to Buzzeo (2011), there are some reading benefits of Readers Theatre which are repeated oral reading in rehearsals and performances supports text fluency. Fluency is reading smoothly at an appropriate rate with accuracy, proper phrasing, and expression. When performance is the goal, students are motivated to read, repeat, and review, re-reading is purposeful and fun. The anticipation of an audience heightens the commitment to rehearsal. Repetition enhances retention. Reader's Theater improves sight word recognition. Reader's Theater boosts listening and speaking skills. Reader's Theater improves reader confidence. Effective performance requires focus from all on script. Student ownership and engagement in the process is high. Because fluency and comprehension are closely related, fluent readers are high achieving students. Support the learning of Bodily-Kinesthetic learners.

In our classroom, we found that student ownership and engagement in the process is high, because fluency and comprehension are closely related, fluent readers are high achieving students. We have not find such commitment to rehearsal because we did it accidentally and this is the first time for all the students to have a readers theater as a method so maybe in the next readers theater method we will announce the play earlier and see the students commitment to read, repeat, and review, re-reading. We also find that this method increases the students listening and speaking skill and also their confidence. It gives a great, fun atmosphere to the classroom and increase their participation and understanding of the topics. Sloyer (2003) explains that readers theater not only improve oral skills but also Readers theater promotes critical thinking, creates good listeners, Advance personal and Social Growth.

Buzzeo (2011) also emphasize the social benefits of readers theater which are the shyest kids often bloom in Reader's theater, collaboration and teamwork are emphasized skills. Reader's theater promotes cooperative interaction with peers, reader's Theater encourages social interaction during reading time and reader's theater encourages practice at home with family members and friends. In our research we found that the social interaction of the students becomes better, the students are having fun together but still managed to capture the essence of the topics which are very good compared to what might happen if we only explain this topic in direct instruction method. Collaboration and teamwork of the students are presence, everybody likes to be involved in the play and everybody wants to understand the concept so Unemployment that was originally a difficult concept can be understood easier.

Cornwell (2012) states some tips for creating a readers theater script which is it is not necessary to use a piece of literature in its entirety. Except can be used very effectively. Be sure to keep in mind the reading level of the readers in selecting a piece of text. Choose text that is within the reach of your readers and that they can read aloud successfully, given repeated practice. Start with picture books. Model how to create a script and create several scripts as a class before asking the students to create their own scripts in small, cooperative groups. Once 
you have selected the piece of text you wish to adapt to script form, show the students how to determine what portions of the text to leave in to be true to the story line, characters, or topic and which portions can be deleted, delete the less critical passages: descriptions, transitions, etc., rewrite or modify those passages that need to be included but require adaptation, keep speeches and narrative passages short, divide the parts for the readers.

We believe that choosing a good script that suitable to the age of the students is very important because a harder script can lead to confusion and boredom. We need to find words that is easy to be understood and to be pronounced and read aloud and try to keep everything simple because it is necessary for these students to understand all concepts while also having a great time at class so everybody will like the materials. Readers Theater has been proven in some cases to improve the reading ability in students. If teachers are to help students increase their reading ability, they must employ used strategies that have been proven to be effective. Also, teachers need to be mindful of the barriers that shape reading difficulties. All students learn differently and need specific instructional strategies that meet their individual needs (Lewis \& Feng, 2014). We also find this in our research in the classroom and students have proven that they can read better with this method.

Readers Theater experience had a positive impact on students' attitudes towards reading and on their overall literacy development, including metacognition, confidence in oral reading, collaboration, and writing. A Student who participated in Readers Theater made dramatic improvements in fluency. Students' test scores indicate a significant growth in reading rate and fluency. Readers Theater provides a successful holistic activity for adolescent learners. When embedded as a regular instructional component of the language arts curriculum, Readers Theater can naturally integrate reading, writing, speaking, and listening within an authentic learning community. Readers Theater enables students to realize success and understand the power of reading in their lives (Rees, 2005).

\section{Conclusion}

Readers Theater is one of the innovative learning in an effort to increase the understanding and value students' learning processes that involve the activity of reading, writing, listening and speaking. In this type of learning students read a manuscript of a certain literature and other students grasp the meaning of what was read and is shown by the reader. Readers Theaters are different from playing drama. In the drama needed costumes, setting room etc., but in this learning not required. Instead of acting out literature as in a play, the performer's goal is to read a script aloud effectively, enabling the audience to visualize the action. Performers bring the text alive by using voice, facial expressions, and some gestures. This paper used readers theater to teach a topic of macroeconomics which is unemployment that often considered as a hard topic. We found that students are very happy with this method. Their reading, writing, listening, and speaking activities are improving and the most important thing is their understanding of unemployment topic is so much better compared to teaching them with only direct instruction method. One of the part that should not be forgotten by teachers are debriefing to check the understanding of the students and many students want this method to be continued especially for another difficult topic so it will be easy to understood. In our classroom, we found that student ownership and engagement in the process is high because fluency and comprehension are closely related, fluent readers are high achieving students. We have not found such commitment to rehearsal because we did it accidentally and this is the first time for all the students to have a readers theater as a method so maybe in the next readers theater method we will announce the play earlier and see the students commitment to read, repeat, and review, re-reading. We also find that this method increases the students listening and speaking skill and also their confidence. It gives a great, fun atmosphere to the classroom and increases their participation and understanding of the topics.

\section{References}

Allan, P. (2015). The Surprising benefit of Role Playing Games. Retrieved from $\mathrm{http} / / /$ lifehacker.com/the-surprising-benefits-of-role-playing-games-and-how-1684582789

Ashton-Hay, S. (2005). Drama: Engaging all learning styles. Paper presented to 9th International INGED (Turkish English Education Association) Conference, Ankara, Turkey, 20-22 October.

Blaug, M. (1985). Economic Theory in Retrospect (4th ed.). Cambridge: Cambridge University Press.

Buzzeo, T. (2011). Readers' Theater in the Classroom and Library: Pathway to Increased Fluency and Comprehension. Retrieved from http://www.tonibuzzeo.com

\section{CEE. (2009). Pasar Tenaga Kerja dan Pengangguran. Council for Economic Education, New York, NY}

Clements, M. D. J. (2007). Role-playing: A learning process to aid supply chain integration. Development and Learning in Organizations: An International Journal, 21(3), 14-16. https://doi.org/10.1108/14777280710739070 
Cornwell, L. (2012). What is readers theater? Scholastic Magazine. Retrieved from http://www.scholastic.com/librarians/programs/whatistt.htm. Accessed on June 07, 2016

Dwivedi, D. N. (2001). Macroeconomics: Theory and policy. New Delhi:Tata McGraw-Hill.

Francis, P., \& Byrne, A. (1999). Use of Role-play Exercises in Teaching Undergraduate Astronomy and Physics. Astronomical Society Australia.

Grafton, S., \& Cross, E. (2008). Dance and the brain. In M. Gazinga (Ed.), Learning, arts, and the brain (pp. 61-69). New York, NY: Dana Press.

Lewis, M., \& Feng, J. (2014). The Effect of Readers' Theatre on the Reading Ability of Elementary Special Education Students. Retrieved from http://files.eric.ed.gov/fulltext/ED557788.pdf

Mace, L. (2015). Bringing Economics Center Stage: Reader's Theater in the Classroom. Retrieved from https://frbatlanta.org/

Mankiw, G. N. (2008). Macroeconomics (6th ed.). Jakarta: Erlangga.

Neely, C. J. (2010). Okun's Law: Output and Unemployment. Economic Synopses, 4. Retrieved from http://research.stlouisfed.org/publications/es/10/ES1004.pdf

Neral, J., \& Ray, M. (1995). Experiential learning in the undergraduate classroom: Two exercises. Economic Inquiry, 33.

Rees, R. M. (2005). The Impact of Participation In Readers Theater on Reading Attitudes and Fluency Skills among Ninth Grade Students in An Alternative Program. A Dissertation Presented to The Graduate Faculty of The University of Akron. Retrieved from https://etd.ohiolink.edu/rws_etd/document/get/akron1133462039/ inline

Samuelson, Paul A.; Solow, Robert M. (1960). Analytical Aspects of Anti-Inflation Policy. American Economic Review, 50(2), 177-194.

Shepard, A. (2004). Readers on Stage. Shepard Publications.

Sloyer, S. (2003). From the Page to the Stage: The Educator's Complete Guide to Readers. Teacher Ideas Press. Libraries Unlimited. A Division of Greenwood Publishing Group, Inc. Westport, Connecticut.

Sutcliffe, M. (2002). Simulations, games and role-play. The Handbook for Economic Lecturers. The Economics Network. Retrieved from: http://www.economicsnetwork.ac.uk/handbook/games/

Willcutt, J. A. (2007). Arts for academic achievement: A brief review of research on readers' theater and tableau in literacy instruction. Center for Applied Research and Educational Improvement. Retrieved from http://conservancy.umn.edu/bitstream/143645/1/AAA-Tableau-and-Readers-Theatre-LitReview.pdf

Wulandari, D., \& Narmaditya, B. S. (2016). Using Simulation Methods to Improve Student Learning. Conference Proceedings $2^{\text {nd }}$ International Conference on Education 2016.

\section{Copyrights}

Copyright for this article is retained by the author(s), with first publication rights granted to the journal.

This is an open-access article distributed under the terms and conditions of the Creative Commons Attribution license (http://creativecommons.org/licenses/by/4.0/). 